\title{
Teori Belajar Behaviorisme: T eori dan Praktiknya dalam Pembelajaran IPS
}

\author{
M isroh Sulaswari \\ Institut Agama Islam N egeri Kudus, Kudus, Indonesia \\ misrohsulaswari@iainkudus.ac.id \\ $N$ ahrul Faidin \\ Universitas N egeri Semarang, Semarang, Indonesia \\ nahrulfaidin1994@.students.unnes.ac.id \\ Muh. Sholeh \\ Universitas N egeri Semarang, Semarang, Indonesia \\ muhsholeh@mail.unnes.ac.id
}

\begin{abstract}
Purpose of this paper is to explain behaviorism learning theory and its application in social studies learning. Using the literature study method through research studies regarding the implications and application of behaviorism learning theory to various learning in schools. Based on the literature review in this paper, it is found that behaviorism learning theory is very suitable to be applied to learning that requires habituation. Behaviorism theory views that the success of a learning is a change in behavior in a positive direction. In addition, behaviorism theory also prioritizes the mechanism for the formation of learning outcomes through stimulus and response procedures. The learning outcomes achieved are the emergence of the desired behavior through practice and repetition so that learning habits are formed. The application of behaviorism learning theory in social studies learning activities depends on several things, such as the learning objectives, the nature of the learning materials, the characteristics of the students, the available media and learning facilities. Through behaviorism theory, social studies learning needs to be linked to situations and conditions that are relevant to the daily lives of students.
\end{abstract}

Keywords: Behaviorism; Learning T eory; Social Studies L earning 


\begin{abstract}
Abstrak
T ujuan dari tulisan ini adalah untuk menjelaskan teori belajar behaviorisme dan penerapannya dalam pembelajaran IPS. M enggunakan metode studi literature melalui kajian penelitian mengenai implikasi dan aplikasi teori belajar behaviorisme terhadap berbagai pembelajaran di sekolah. Berdasarkan kajian literatur pada tulisan ini menemukan bahwa teori belajar behaviorisme sangat cocok diterapkan kepada pembelajaran yang membutuhkan pembiasaan. Teori behaviorisme memandang bahwa keberhasilan dari suatu pembelajaran adalah adanya perubahan tingkah laku ke arah positif. Selain itu, teori behaviorisme juga mengutamakan mekanisme terbentuknya hasil belajar melalui prosedur stimulus dan respon. $\mathrm{H}$ asil belajar yang dicapai adalah munculnya perilaku yang diinginkan melalui latihan dan pengulangan sehingga terbentuk kebiasaan belajar. Penerapan teori belajar behaviorisme dalam kegiatan pembelajaran IPS tergantung dari beberapa hal seperti, tujuan pembelajaran, sifat materi pembelajaran, karakteristik peserta didik, media dan fasilitas pembelajaran yang tersedia. M elalui teori behaviorisme maka pembelajaran IPS perlu dikaitkan dengan situasi dan kondisi yang relevan dengan kehidupan sehari-hari peserta didik.
\end{abstract}

Kata kunci: Behaviorisme; T eori Belajar; Pembelajaran IPS

\title{
A. Pendahuluan
}

Pendidikan IPS memiliki tujuan untuk mempersiapkan peserta didik menjadi warga negara yang baik ( good citizenship). Fungsi dan kedudukan IPS adalah mengantarkan peserta didik dalam memahami perannya, hak dan kewajibannya, serta bertanggung jawab sebagai warga negara Indonesia yang baik. M elalui pendidikan IPS peserta didik dibekali keterampilan yang berguna untuk masyarakat. Pendidikan IPS didesain didasarkan pada masalah dan realitas sosial melalui pendekatan interdisipliner (Syaharuddin and M utiani 2020).

Pembelajaran IPS diperlukan untuk membimbing masyarakat Indonesia menuju self understanding of nation dalam rangka mengatasi masalah pembangunan dan pembinaan bangsa (nation and character building). U ntuk itulah pembelajaran IPS lebih menekankan aspek sikap dan perilaku daripada transep konsep karena dalam pembelajaran IPS, peserta didik dibekali pemahaman sejumlah konsep serta pengembangan sikap, nilai, moral, dan keterampilan berdasarkan konsep yang dimilikinya. Tujuan pembelajaran IPS adalah mengembangkan potensi peserta didik agar peka terhadap masalah sosial yang terjadi pada masyarakat, memiliki sikap mental positif terhadap perbaikan segala ketimpangan yang terjadi 
dan melatih keterampilan untuk mengatasi setiap masalah yang terjadi sehari-hari baik yang menimpa diri sendiri atau masyarakat sekitar (Syaharuddin and M utiani 2020).

Salah satu teori pembelajaran yaitu behaviorisme yang memandang perubahan perilaku sebagai tujuan akhir pembelajaran dipandang sangat relevan dengan karakteristik pembelajaran IPS tersebut. M enurut teori behaviorisme, belajar dipahami sebagai perubahan perilaku yang dapat diamati secara langsung, terjadi dalam waktu yang cukup lama sebagai hasil dari pengalaman dengan lingkungan (Asfar 2019). Perubahan tingkah laku tersebut dalam proses belajar melalui interaksi antara stimulus dan respon. Penelitian Asfar (2019) selanjutnya menemukan bahwa dalam penerapannya, teori behaviorisme sangat cocok untuk memperoleh kemampuan yang membutuhkan praktik dan pembiasaan.

Berdasarkan tujuan pembelajaran IPS yang lebih menekankan aspek perubahan sikap dan tingkah laku maka penggunaan teori behaviorisme dapat disesuaikan melalui pemberian stimulus yang tepat agar menghasilkan respon yang baik sesuai tujuan. Tulisan ini memberikan penjelasan pentingnya pembelajaran IPS melalui pendekatan teori belajar behaviorisme dan pembelajaran bermakna sehingga terjadi perubahan perilaku peserta didik. Kebaruan dalam tulisan ini yaitu terdapat langkah-langkah pembelajaran IPS yang dapat diterapkan oleh guru IPS sesuai pendekatan teori belajar behaviorisme.

M etode penelitian ini menggunakan studi literatur dari berbagai penelitian bermaksud menguraikan implikasi teori belajar behaviorisme dalam pembelajaran IPS sehingga terjadi perubahan perilaku yang sesuai dengan tujuan pendidikan IPS. Tujuan utama dari studi literatur adalah untuk mengembangkan aspek teoritis dan aspek manfaat praktis terkait pembelajaran IPS dalam pendekatan teori belajar behaviorisme. Selain itu, studi literatur dilakukan sebagai dasar untuk membangun landasan teori dan kerangka berpikir (Darmadi, 2011). Studi literatur dalam tulisan ini bertujuan untuk mempertajam ide dan menemukan metode yang cocok dalam pembelajaran IPS sesuai pendekatan teori belajar behaviorisme.

Data yang digunakan berasal dari artikel ilmiah hasil penelitian tentang implikasi dan aplikasi teori belajar behaviorisme dalam suatu pembelajaran di sekolah. Selanjutnya analisis data dilakukan dengan membuat catatan, kutipan, informasi yang disusun secara sistematis sesuai relevansinya dengan ide penelitian. Setelah keseluruhan data terkumpul, dilakukan teknik analisis isi (content analysis). Langkah terakhir yaitu menyusun bibliografi untuk menghindari plagiasi. 


\section{B. Pembahasan}

\section{Teori Belajar Behaviorisme}

Menurut teori belajar behaviorisme memandang belajar sebagai perubahan tingkah laku yang terjadi melalui hubungan stimulus dan respon. Teori belajar behaviorisme berorientasi pada perubahan perilaku yang lebih baik. Para tokoh behaviorisme berpendapat bahwa peserta didik cukup mengasosiasikan stimulus-stimulus dan respon yang diberi reinforcement sehingga peserta didik memberikan respon yang benar (Rufaedah, 2018). Behaviorisme menganggap setiap anak manusia lahir tanpa warisan kecerdasan, bakat, perasaan, dan warisan yang bersifat abstrak lainnya, serta manusia bersifat mekanistik dimana manusia merespon lingkungannya dengan kontrol yang terbatas dan mempunyai peran sedikit terhadap dirinya sendiri (Syah, 2004).

Konsep behaviorisme memandang bahwa perilaku individu sebagai hasil belajar yang dapat diubah melalui manipulasi dan memodifikasi kondisi-kondisi belajar yang didukung oleh berbagai penguatan atau reinforcement untuk mempertahankan perilaku sebagai hasil belajar yang dikehendaki (Sanyata, 2012). Perubahan perilaku akan muncul setelah manusia mengalami interaksi dengan lingkungan alam dan sosial budayanya selama proses pendidikan. Individu akan menjadi pintar, terampil, dan mempunyai perilaku baik lainnya tergantung pada pembelajarannya dengan lingkungan tersebut.

Teori belajar behaviorisme sangat menekankan pada hasil belajar berupa perubahan perilaku yang harus dapat diamati dan dikur. $\mathrm{H}$ asil belajar tersebut diperoleh dari proses penguatan stimulus dan respon yang muncul terhadap lingkungan belajar baik internal maupun eksternal. Belajar diartikan sebagai penguatan ikatan asosiasi sifat dan kecenderungan untuk merubah perilaku ( $N$ ahar, 2016). Belajar dalam pandangan teori behaviorisme merupakan aktivitas dari stimulus dan respon. Stimulus adalah rangsangan yang diberikan sehingga terjadi perubahan perilaku aktif dan aksi atau tindakan. Sementara respon adalah segala perbuatan dan tingkah laku yang diakibatkan adanya stimulus tersebut (Suswandari 2021).

Salah satu tokoh teori behaviorisme yaitu Thorndike mengemukakan hukum adanya stimulus dan respon, yaitu: (1) H ukum Kesiapan (law of readiness) yaitu perubahan tingkah laku karena adanya kesiapan dari individu sehingga memunculkan kepuasan pada diri individu tersebut, (2) Hukum Latihan ( law of exercise) yaitu intensitas tingkah laku yang dilatih atau digunakan akan memperkuat aktivitas tersebut, (3) Hukum Akibat (law of effect) yaitu hubungan linearitas antara stimulus dengan respon akan semakin kuat apabila hubungan 
tersebut bersifat menyenangkan (Suswandari 2021). Pada tulisan Pratama (2019) menambahkan hukum keempat, yaitu Hukum Sikap (law of attitude) yang memandang perilaku belajar tidak hanya ditentukan oleh hubungan stimulus dan respon saja, juga ditentukan oleh keadaan yang ada dalam diri individu menyangkut aspek kognitif, emosi, sosial, dan psikomotoriknya (Pratama 2019).

Pendekatan pembelajaran behaviorisme dalam pandangan Thorndike disebut dengan teori connectionism yang memiliki ciri-ciri diantaranya: (1) adanya aktivitas, (2) adanya berbagai respon terhadap berbagai situasi, (3) adanya eliminasi terhadap berbagai respon yang salah, dan (4) adanya kemajuan reaksi-reaksi mencapai tujuan. Teori connectionism ini disebut juga dengan trial and error (Rosiyanti \& Purnomo, 2019).

Tokoh behaviorisme lainnya yaitu Skinner terkenal dengan konsep operant conditioning menekankan pentingnya pengkondisian pembelajaran untuk meningkatkan perilaku peserta didik. Pembelajaran operant conditioning adalah bertujuan untuk memastikan terbentuknya respon terhadap stimulus yang diberikan oleh guru. Maka peran guru adalah memberikan stimulus berupa materi pelajaran yang kontekstual, kemudian guru memberikan reinforcement untuk memunculkan semangat belajar peserta didik (Suswandari 2021) .

Prinsip teori belajar behaviorisme dalam penerapannya terdiri dari 3 hal ( $M$ ukinan, 1997) yaitu: (1) apabila individu sudah mampu menunjukkan perubahan perilaku, maka dikatakan individu sudah belajar, artinya kegiatan belajar yang tidak membawa perubahan perilaku tidak dianggap belajar; (2) hal yang paling penting pada teori belajar behaviorisme adalah stimulus dan respon karena bisa diamati, sementara hal-hal selain stimulus dan respon tidak dianggap penting karena tidak bisa diamati; (3) adanya penguatan ( reinforcement) yaitu hal-hal yang bisa memperkuat respon baik bersifat positif maupun negatif.

Secara umum teori belajar behaviorisme memiliki ciri-ciri sebagai berikut, diantaranya: (1) mengutamakan unsur-unsur atau bagian-bagian kecil, (2) bersifat mekanis, (3) menekankan peranan lingkungan, (4) mementingkan pembentukan respon, (5) mementingkan latihan dan pembiasaan (Suyono \& H ariyanto, 2011). Konsep belajar menurut teori behaviorisme seperti pada gambar 1 yang memperlihatkan perilaku individu sebelum dan sesudah mendapat stimulus. 


\begin{tabular}{|c|c|c|}
\hline Perilaku \\
Individu \\
Sebelum \\
Belajar \\
(pre learning)
\end{tabular}$\longrightarrow \begin{gathered}\text { Pengalaman, } \\
\text { Praktik, dan } \\
\text { Latihan } \\
\text { (learning } \\
\text { experience) }\end{gathered} \longrightarrow$\begin{tabular}{c} 
Perilaku \\
Individu \\
Sesudah \\
Belajar \\
(post learning) \\
\hline
\end{tabular}

Gambar 1. Konsep Belajar Behaviorisme

Menurut aliran behaviorisme belajar pada hakikatnya ialah merupakan proses pembentukan asosiasi antara kesan yang ditangkap panca indera dengan kecenderungan untuk bertindak antara stimulus dan respon, sehingga dalam teoriini belajar dapat dipahami sebagai upaya untuk membentuk hubungan antara stimulus dan respon sebanyak-banyaknya ( Sanjaya, 2018). M enurut teori behaviorisme perubahan perilaku manusia sangat dipengaruhi oleh lingkungan yang akan memberikan beragam pengalaman kepada kehidupan seseorang. Lingkungan merupakan stimulus yang dapat mempengaruhi atau mengubah kapasitas untuk respon.

Belajar merupakan hasil dari interaksi antara rangsangan dan tanggapan. Suatu individu dianggap telah belajar apabila dapat memperlihatkan perubahan tingkah lakunya. Teori behaviorisme ini menganggap hal yang penting dalam proses belajar adalah masukan yang berupa rangsangan (stimulus) dan hasil berupa respon (tanggapan). Stimulus adalah rangsangan yang dilakukan oleh guru sedangkan respon adalah tanggapan atas Stimulus yang telah diberikan oleh guru itu sendiri. Proses yang terjadi antara Stimulus dan respon tidak perlu untuk diamati karena tidak dapat dikur, akan tetapi stumulus dan respon lah yang dapat diamati. M aka dari itu, stimulus yang diberikan guru dan respon yang diterima peserta didik dapat diukur dan diamati (Putrayasa, 2013) .

Berdasarkan dari berbagai penjelasan di atas dapat dipahami bahwa dalam proses pembelajaran dengan menggunakan teori Behavioristik, manusia dituntut untuk lebih cenderung responsif terhadap stimulus-stimulus yang diberikan kemudian menghasilkan prilaku yang baik. Dalam lingkup akademik ada beberapa prinsip umum yang harus diketahui yaitu: (1) Teori ini berpendapat bahwa yang dikatakan belajar adalah perubahan prilaku. Disebut telah belajar apabila sudah dapat menujjukan perubahan yang terjadi dalam pola tingkah lakunya. (2) Teori ini berpendapat bahwa urgensi dari belajar adalah terjadinya rangsangan (stimulus) dan tanggapan (respon) karena inilah bisa di amati. Sedangkan yang 
terjadi diantarnya dianggap tidak bisa diamati. (3) Penguatan (reinforcement), apa saja yang dapat menjadi penguat terhadap penunjang responsive, semakin banyak penguatan maka rensposif pun akan semakin kuat ( $M$ ajid and Suyadi 2020).

M enurut $G$ agne dan Briggs belajar adalah hasil ransangan dan respon yang secara terus menerus diberikan penguatan (Reinforcement) (Gagne \& Briggs, 2008). Reinforcement dimaksud yaitu bagaimana pola tingkah laku seseorang mampu untuk di kuatkan dalam proses pembelajaran sehingga mencapai hasil yang lebih baik. Dalam proses belajar tentu ada target yang ingin dicapai sebagaimana dalam buku $\mathrm{N}$ ana Sudjana yang dikutip oleh F redy Kustanto menjelaskan bahwa ada beberapa aspek yang hendak dicapai dalam proses belajar yakni aspek kognitif, efektif, dan psikomotorik (Kustanto, 2016).

Berdasarkan analisis dari beberapa tokoh teori belajar Behaviorisme ( $M$ uflihin, 2009) maka dapat diklasifikasikan persamaan dan perbedaan diantarnya seperti pada tabel 1.

\begin{tabular}{|c|c|c|}
\hline No & Persamaan & Perbedaan \\
\hline 1 & $\begin{array}{l}\text { M enekankan pada perubahan perilaku sebagai } \\
\text { hasil belajar }\end{array}$ & $\begin{array}{l}\text { M enurut Pavlov: Seseorang dalam Proses belajar } \\
\text { melibatkan adanya respon kondisi, pengulangan } \\
\text { stimulus tanpa stimulus utama, kemudian ada } \\
\text { respon kondisi dengan satu stimulus, disitulah } \\
\text { individu belajar menghasilkan respon kondisi } \\
\text { pada satu stimulus, namun tidak dari stimulus } \\
\text { yang sama dan kondisi berbeda. }\end{array}$ \\
\hline 2 & $\begin{array}{l}\text { T eori behaviorisme menjelaskan bahwa dalam } \\
\text { proses belajar selalu melibatkan adanya } \\
\text { stimulus dan respon serta mementingkan } \\
\text { pengaruh lingkungan dan peranan reaksi }\end{array}$ & $\begin{array}{l}\text { M enurut Thorndike: Seseorang dalam proses } \\
\text { belajar, untuk mencapai hubungan stimulus dan } \\
\text { respon perlu adanya kemampuan untuk memilih } \\
\text { respon yang tepat serta melalui usaha-usaha atau } \\
\text { percobaan-percobaan dan kegagalan-kegagalan } \\
\text { (trial and error). }\end{array}$ \\
\hline 3 & $\begin{array}{l}\text { T eori behaviorisme berpendapat bahwa setiap } \\
\text { anak manusia lahir tanpa warisan kecerdasan, } \\
\text { warisan bakat, dan warisan lain yang bersifat } \\
\text { abstrak }\end{array}$ & $\begin{array}{l}\text { M enurut W atson: Belajar merupakan proses } \\
\text { terjadinya refleks-refleks bersyarat melalui } \\
\text { stimulus pengganti, menurutnya manusia } \\
\text { dilahirkan dengan beberapa reflex dan reaksi- } \\
\text { reaksi emosional berupa takut, cinta dan marah. } \\
\text { Jadi ada hubungan antara stimulus dan respon. }\end{array}$ \\
\hline 4 & $\begin{array}{l}\text { Teori behaviorisme memandang individu } \\
\text { hanya dari fenomena jasmani dan mengabaikan } \\
\text { aspek-aspek mental }\end{array}$ & $\begin{array}{l}\text { M enurut H ull: tingkah laku seseorang dalam } \\
\text { belajar berfungsi untuk menjaga kelangsungan } \\
\text { hidup. O leh karena itu kebutuhan biologis dan } \\
\text { pemuasan kebutuhan biologis menempati posisi } \\
\text { sentral. Sehingga K ebutuhan digunakan sebagai } \\
\text { sebuah dorongan, stimulus ( tujuan, maksud, } \\
\text { ambisi, aspirasi) yang harus dikaitkan dengan } \\
\text { kebutuhan biologis. }\end{array}$ \\
\hline
\end{tabular}




\begin{tabular}{|c|c|c|}
\hline 5 & $\begin{array}{l}\text { Teori behaviorismetidak mengakui adanya } \\
\text { bakat, minat, kecerdasan, dan perasaan individu } \\
\text { dalam proses belajar }\end{array}$ & $\begin{array}{l}\text { M enurut G uthrie: Penguatan dalam belajar } \\
\text { hanya bersifat sementara yaitu sekedar untuk } \\
\text { melindungi hasil belajar yang baru agar tidak } \\
\text { hilang karena adanya respon yang baru. G uthrie } \\
\text { percaya bahwa hukuman memegang peranan } \\
\text { dalam proses belajar. }\end{array}$ \\
\hline 6 & $\begin{array}{l}\text { Peristiwa belajar semata-mata melatih reflek- } \\
\text { reflek sedemikian rupa sehingga menjadi } \\
\text { kebiasaan yang dikuasai individu dengan kata } \\
\text { lain mementingkan pembentukan kebiasaan } \\
\text { melalui latihan dan pengulangan }\end{array}$ & $\begin{array}{l}\text { M enurut Skinner: seseorang yang belajar harus } \\
\text { diberikan penguatan atau reinforcementsehingga } \\
\text { proses belajar cenderung diulangi jika tidak maka } \\
\text { cenderung akan menghilang dan terapus, namun } \\
\text { skinner tidak setuju dengan adanya hukuman, } \\
\text { karena hukuman dapat berdampak buruk } \\
\text { terhadap perubahan tingkah laku. }\end{array}$ \\
\hline
\end{tabular}

T abel 1. Persamaan dan Perbedaan T eori Behaviorisme M enurut T okoh

\section{Pembelajaran IPS M enurut T eori Belajar Behaviorisme}

Penerapan teori belajar behaviorisme dalam kegiatan pembelajaran tergantung dari beberapa hal misalnya, tujuan pembelajaran, sifat materi pembelajaran, karakteristik peserta didik, media dan fasilitas pembelajaran yang tersedia. Pembelajaran yang dirancang dan berpijak pada teori behaviorisme memandang pengetahuan adalah obyektif, pasti, tetap, dan tidak berubah. Pengetahuan telah terstruktur dengan rapi sehingga belajar merupakan perolehan pengetahuan, sementara mengajar merupakan proses memindahkan pengetahuan ( transfer of knowledge) kepada peserta didik yang belajar. Fungsi mind atau pikiran adalah untuk mendapatkan struktur pengetahuan yang sudah ada melalui proses berpikir, dianalisis dan dipilah sehingga membentuk makna dari proses berpikir tersebut disebabkan karakteristik struktur pengetahuan ( Asfar, 2019).

Fokus utama dalam teori belajar behavioristik adalah perilaku yang terlihat dan penyebab luar yang menstimulasinya. Jika dalam teori behavioristik lebih menekankan perkembangan pola perilaku dalam pembelajaran, maka yang menjadi unsur penentu keberhasilnya adalah G uru itu sendiri. O lehnya itu, sekiranya Guru harus memperhatiakan halhal sebagai berikut: (1) Guru harus paham akan perannya yaitu memberikan stimulus yang tepat untuk peserta didik (2) Guru harus memahami respon atau tanggapan yang kiranya akan muncul dari peserta didik. ( 3) U ntuk mengetahui respon yang diperlihatkan oleh peserta didik, maka guru harus mampu menetapkan respon itu, apakah bisa diamati atau tidak, mampu mengukur respon yang ditunjukkan oleh peserta didik dan respon yang di tunjukkan oleh peserta didik mampu untuk dianalisis kejelasan maknanya. (4) Agar respon tersebut dianggap 
berkesan, maka perlu adanya penghargaan dari guru atas capaian peserta didik ( $M$ ajid and Suyadi 2020).

T eori behaviorisme memandang bahwa keberhasilan dari suatu pembelajaran adalah adanya perubahan tingkah laku ke arah positif. Selain itu, teori behaviorisme juga mengutamakan mekanisme terbentuknya hasil belajar melalui prosedur stimulus dan respon. $\mathrm{H}$ asil belajar yang dicapai adalah munculnya perilaku yang diinginkan melalui latihan dan pengulangan sehingga terbentuk kebiasaan belajar.

Ada beberapa cara yang dapat dilakukan oleh guru dalam menerapkan teori behaviorisme pada proses pembelajaran (M ukinan, 1997), yaitu:

1) M engenali tujuan pembelajaran

2) M elakukan analisis pada pembelajaran

3) M engidentifikasi karakteristik dan kemampuan awal pembelajaran

4) M enetapkan indikator yang dapat menunjang keberhasilan pembelajaran

5) M elakukan pengembangan materi ajar seperti pokok pembahasan, topik, dan lain-lain

6) M elakukan pengembangan strategi pembelajaran seperti metode, media, kegiatan, dan waktu

7) M elakukan pengamatan terhadap stimulus apa yang dapat diberikan kepada peserta didik seperti latihan, tes, tugas, dan sejenisnya

8) M enganalisis dan memahami tanggapan peserta didik terhadap pembelajaran

9) M emberikan penguatan atau reinforcement baik positif atau negatif

10) M engevaluasi diri setelah melakukan pembelajaran untuk memperbaiki kekurangan

Salah satu tema pembelajaran IPS yaitu tema global connections seperti yang terdapat pada materi perubahan sosial budaya dan globalisasi untuk kelas 9 mata pelajaran IPS SM P. D engan menggunakan teori behaviorisme maka proses pembelajaran IPS dapat dilaksanakan dengan memberikan stimulus terkait perubahan sosial budaya dan globalisasi untuk melihat respon peserta didik serta diberikan latihan, pengulangan, dan tidak ketinggalan pemberian penguatan agar materi dapat dipahami dengan baik oleh peserta didik. Langkah-langkah yang dapat dilakukan oleh guru IPS dalam melakukan proses pembelajaran menggunakan teori behaviorisme sesuai pendapat M ukinan (1997) yang telah disebut di atas, yaitu: 
Pertama, merumuskan tujuan pembelajaran. Guru IPS dapat merumuskan tujuan pembelajaran dengan materi Perubahan Sosial Budaya dan Globalisasi sesuai teori behaviorisme dengan rumus ABCD (Audience, Behavior, Condition, Degree) contohnya "melalui penayangan video, peserta didik mampu memberikan contoh bentuk perubahan sosial budaya dan globalisasi yang terjadi pada masyarakat Indonesia dengan tepat" Maka disini terlihat stimulusnya adalah penayangan video berupa bentuk-bentuk perubahan sosial budaya dan globalisasi. Sedangkan perilaku yang diinginkan adalah peserta didik mampu memberikan contoh bentuk perubahan sosial budaya dan globalisasi.

Kedua, guru memberikan instruksi singkat diikuti dengan pemberian contoh atau simulasi. M isalnya memberikan contoh yang dekat dengan kehidupan sehari-hari peserta didik. Guru dapat memberikan stimulus juga dengan cara menanyakan perubahan yang terjadi pada diri peserta didik ketika pembelajaran saat ini lebih banyak daring. Guru dapat mengamati respon yang diberikan oleh para peserta didik dari jawaban yang mereka lontarkan sebagai pengetahuan awal peserta didik.

Ketiga, guru menyampaikan materi pelajaran dimulai dari yang sederhana menuju yang kompleks. Maksudnya adalah materi disusun mulai dari yang mudah dipahami sampai yang sulit dipahami oleh peserta didik. $\mathrm{H}$ al ini bisa dilihat dari kata kerja operasional yang terdapat pada kompetensi dasar (Peraturan M enteri Pendidikan dan Kebudayaan nomor 37 tahun 2018). Pada materi perubahan sosial budaya dan globalisasi, terlihat kata kerja operasionalnya adalah menganalisis yang merupakan level kognitif keempat (C4) dalam taksonomi Bloom dan Anderson, maka guru dalam menyusun materi harus dimulai dari level kognitif paling rendang atau C1 misalnya menjelaskan, menyebutkan, memahami, dan lainlain. Baru yang terakhir adalah menganalisis. O leh karena itulah, pertemuan awal guru harus menyampaikan terlebih dahulu tentang pengertian perubahan sosial budaya dan apa itu globalisasi kepada peserta didik melalui contoh-contoh tadi.

Keempat, setelah mendapatkan respon dari peserta didik maka segera melakukan reinforcement atau penguatan. Ketika ada peserta didik yang menjawab dengan salah maka guru harus segera memperbaiki kesalahan dan ketika peserta didik merespon dengan benar maka segera pula diapresiasi mungkin bisa dengan memberi tepuk tangan dan sebagainya. $\mathrm{H}$ al ini bertujuan agar peserta didik selalu ingat apa yang mereka dapatkan dan akhirnya memahami materi.

Kelima, pemberian latihan dan pengulangan. Dalam hal ini guru selalu melatih peserta didik untuk menjawab pertanyaan seputar materi perubahan sosial budaya dan globalisasi serta diulang-ulang. Contohnya: memberi pertanyaan sesuai tujuan pembelajaran yaitu 
menyebutkan bentuk-bentuk perubahan sosial budaya dan contoh globalisasi kepada salah satu peserta didik, setelah direspon oleh peserta didik tersebut dan guru memberikan penguatan, lalu diulang kembali dengan pertanyaan serupa kepada peserta didik yang lain, kemudian tanggapi respon dan ulangi lagi dengan peserta didik yang lain lagi begitu seterusnya sampai peserta didik menjadi terbiasa dan akhirnya memahami materi.

Keenam, melakukan evaluasi berdasarkan perilaku peserta didik yang tampak. Jadi harus diingat oleh guru bahwa keberhasilan dari suatu pembelajaran adalah perubahan perilkau yang awalnya tidak tahu menjadi tahu. M aka guru perlu melakukan penilaian terhadap perilaku peserta didik yang didasarkan pada mekanisme pemberian stimulus dan respon peserta didik yang telah dilakukan saat pembelajaran tadi. Proses evaluasi ini dilakukan sesuai dengan kriteria yang telah ditentukan ( $\mathrm{H}$ anik 2020). Dari hasil evaluasi dapat ditemukan mana saja peserta didik yang perlu diberi latihan dan pengulangan lagi. $\mathrm{H}$ al ini dimaksudkan agar seluruh peserta didik memahami materi tentang perubahan sosial budaya dan globalisasi.

Suatu pembelajaran akan menjadi powerfull apabila pembelajaran tersebut bermakna (meaningfull). Pembelajaran bermakna merupakan gagasan yang dicetuskan oleh David Ausubel yang berarti suatu proses pembelajaran hendaknya mengkaitkan antara informasiinformasi yang baru terhadap konsep-konsep yang relevan dengan struktur kognitif peserta didik. M elalui pembelajaran bermakna maka pengetahuan yang diterima akan bertahan lama dalam ingatan peserta didik. Melalui teori behaviorisme maka pembelajaran IPS perlu dikaitkan dengan situasi dan kondisi yang relevan dengan kehidupan sehari-hari peserta didik. Perlu diingat bahwa teori behaviorisme menekankan pada pemberian stimulus dan respon sehingga terjadi perubahan perilaku sebagai hasil pembelajaran. 0 leh karena itulah, stimulus yang diberikan oleh guru sebaiknya adalah contoh-contoh yang kontekstual dalam arti materi yang disampaikan sebagai stimulus merupakan informasi yang dekat dengan kehidupan peserta didik.

Sebagai contoh: dalam materi globalisasi dan perubahan sosial budaya peserta didik diberikan contoh mengenai perubahan sosial budaya yang terjadi di masyarakat sekitar mereka. $M$ ateri globalisasi disampaikan dengan memberikan stimulus mengenai pemakaian gadget dan media sosial yang memang sudah dekat dengan kehidupan dunia peserta didik. Pemberian stimulus yang kontekstual akan menjadikan pembelajaran IPS bermakna karena akan terus teringat oleh peserta didik sehingga mudah dipahami. 
Selain itu, pembelajaran IPS yang powerfull perlu dilakukan oleh guru dengan bantuan media pembelajaran. Proses pembelajaran akan lebih menarik, karena terdapat beberapa variasi pembelajaran( Ramadhani 2021), seperti penggunaan media video tayangan mengenai globalisasi dan perubahan sosial budaya yang terjadi masyarakat Indonesia (perdesaan atau perkotaan) sesuaikan dengan situasi dan kondisi dimana peserta didik tinggal. M elalui media video peserta didik menjadi tertarik dengan pembelajaran IPS sehingga proses pembelajaran menjadi lebih hidup dan aktif karena tidak satu arah.

\section{Simpulan}

Teori belajar Behaviorisme merupakan salah satu aliran dalam filsafat teori pembelajaran yang menekankan pentingnya perubahan perilaku sebagai hasil belajar melalui hubungan stimulus dan respon. Proses pembelajaran IPS dengan menggunakan teori Behavioristik, maka peserta didik dituntut untuk lebih responsif terhadap stimulus-stimulus yang diberikan oleh guru agar menghasilkan perilaku yang baik. Belajar merupakan hasil dari interaksi antara rangsangan dan tanggapan. Peserta didik dianggap telah belajar apabila dapat memperlihatkan perubahan tingkah lakunya. Teori behaviorisme menganggap hal yang penting dalam proses belajar adalah masukan yang berupa rangsangan (stimulus) dan hasil berupa respon (tanggapan). Stimulus adalah rangsangan yang dilakukan oleh guru sedangkan respon adalah tanggapan atas stimulus yang telah diberikan oleh guru itu sendiri. Penerapan teori belajar behaviorisme dalam kegiatan pembelajaran IPS tergantung dari beberapa hal seperti, tujuan pembelajaran, sifat materi pembelajaran, karakteristik peserta didik, media dan fasilitas pembelajaran yang tersedia.

Salah satu tema pembelajaran IPS yaitu tema global connections seperti yang terdapat pada materi perubahan sosial budaya dan globalisasi untuk kelas 9 mata pelajaran IPS SM P. D engan menggunakan teori behaviorisme maka proses pembelajaran IPS dapat dilaksanakan dengan memberikan stimulus terkait perubahan sosial budaya dan globalisasi untuk melihat respon peserta didik serta diberikan latihan, pengulangan, dan tidak ketinggalan pemberian penguatan agar materi dapat dipahami dengan baik oleh peserta didik. Melalui teori behaviorisme maka pembelajaran IPS perlu dikaitkan dengan situasi dan kondisi yang relevan dengan kehidupan sehari-hari peserta didik. Perlu diingat bahwa teori behaviorisme menekankan pada pemberian stimulus dan respon sehingga terjadi perubahan perilaku sebagai hasil pembelajaran. O leh karena itulah, stimulus yang diberikan oleh guru sebaiknya adalah contoh-contoh yang kontekstual dalam arti materi yang disampaikan sebagai stimulus merupakan informasi yang dekat dengan kehidupan peserta didik. 


\section{DAFTAR PUSTAKA}

Asfar, A.M . irfan T aufan Asfar \& andi muhammad iqbal. 2019. "TEORI BEHAVIORISME ( Theory of Behaviorism )." Researchgate(February): 0-32.

Hanik, Elya Umi. 2020. "Self Directed Learning Berbasis Literasi Digital Pada M asa Pandemi Covid-19 Di Madrasah Ibtidaiyah." ELEM EN TARY: Islamic Teacher Journa/8(1) : 183.

Majid, Muhammad Fadhil Alghi Fari, and Suyadi Suyadi. 2020. "Penerapan Teori Belajar Behavioristik Dalam Pembelajaran PAI Muhammad." Jurnal PAI Raden Fatah 2(2): 148-55.

Muh. Hizbul Muflihin. 2009. "DALAM PEMBELAJARAN ( Analisis Strategis Inovasi Pembelajaran )." Jurnal //miah Kependidikan Vol 1 N 02(ISSN :1979-6668) : 11.

Pratama, Yoga Anjas. 2019. "Relevansi Teori Belajar Behaviorisme Terhadap Pendidikan Agama Islam." Jurnal Pendidikan A gama Islam Al-Thariqah 4( 1) : 38-49.

Ramadhani, Elya Umi Hanik dan Annisa Dita. 2021. "Penerapan Strategi Pembelajaran Flipped Classroom Sebagai Implementasi Dari Blended Learning Pada M asa Pandemi Covid-19 Di MI NU Miftahul Falah Undaan Tengah Application." el Bidayah: Journal of Islamic Elementary Education 3(September) : 115-30.

Rosiyanti, Hastri (Universitas Muhammdiyah Jakarta), and Yadhi Purnomo (Universitas M uhammadiyah Jakarta). 2019. "Kemampuan Berpikir Kritis Peserta Didik Dalam Pembelajaran Teori Behavioristik 1, 2).” : 61-64.

Safaruddin, Safaruddin. 2020. “Teori Belajar Behavioristik.” Jurnal Al-Q alam: Jurnal Kajian Islam \& Pendidikan 8(2) : 119-35.

Suswandari, M eidawati. 2021. "Peran Guru Menstimulus Respon Siswa Melalui Teori Belajar Behavioristik Teacher'S Role Stimulates Students' Response Through Behavioristic Learning Theory." Absorbent Mind: Journal of Psychology and Child Development A valiable1(1) : 47-55.

Syaharuddin, and Mutiani. 2020. Pendidikan Strategi Pembelajaran IPS: Konsep Dan Aplikasi.

Syah, M uh. (2004) . Psikologi Belajar. Jakarta: PT . RajaG rafindo Persada. 
Misroh Sulaswari, $N$ ahrul faidin, M uh Sholeh 